\title{
Emoticons are not for everyone: The role of congruence between hotel brand positioning strategies and communication style in enhancing customers' brand attitude and booking intention
}

Tourism and Hospitality Research 2021, Vol. 2l(3) 317-329 (C) The Author(s) 2021 Article reuse guidelines: sagepub.com/journals-permissions DOI: 10.1177/1467358421993901 journals.sagepub.com/home/thr (\$SAGE

\author{
Sabrina M Hegner (1) \\ City University of Applied Science Bremen, Bremen, Germany \\ Carlotta Lotze \\ University of Applied Sciences Bielefeld, Bielefeld, Germany
}

\section{Ardion Daroca Beldad}

Corporate and Marketing Communication, University of Twente, Enschede, Netherlands

\begin{abstract}
Social media has become an influential communication channel, and brands are increasingly using an informal style in their social media communication. Nonetheless, despite this development, little research has addressed the influence of social media communication style on brand perceptions. Hence, this study addresses the question on how the interaction of employing different communication styles and different hotel positioning strategies affects consumers' perceptions and booking intentions in the hotel industry. Additionally, this study explores whether the fit between communication style and hotel positioning mediates the relationship on brand attitude and booking intention. A $2 \times 2$ between-subjects full-factorial design with 336 participants was conducted. Results of the experiment show that an informal communication style can be harmful for a utilitarian positioned hotel. A perception of fit between brand positioning and communication style leads to a more favorable brand attitude and higher booking intention. Despite the tendency for brands to increasingly use an informal style in their social media communication, only little research has analyzed the impact of communication style on consumer perceptions. Furthermore, considering a hotel's positioning represents an important moderator in this relationship.
\end{abstract}

\section{Keywords}

Communication style, brand positioning, consumer attitude, experiment, structural equation model

\section{Introduction}

Social media has become an important tool for branding and consumer marketing (Benevolo and Spinelli, 2016; Jahn and Kunz, 2012; Kwok and Yu, 2016), and most brands include it in their marketing communication strategy (Beukeboom et al., 2015). The adoption of social media represents a new opportunity for brands to connect and engage with consumers as consumer-brand interactions are increasing (Jahn and Kunz, 2012; Kwok et al., 2019; Loo, 2020). Nearly $90 \%$ of the Fortune 500 companies have established an active business page on Facebook (Cohen, 2018). Overall, social media has become an influential

\footnotetext{
Corresponding author:

Sabrina M Hegner, City University of Applied Science Bremen, Werderstr. 73, 28199 Bremen, Germany.

Email: sabrina.hegnerahs-bremen.de
} 
communication channel that enables brands to build relationships and interact with their customers (Kwok et al., 2019; Zailskaite-Jakste et al., 2017).

Particularly, the tourism industry has been significantly affected by social media as travelers widely search, organize, share, and annotate travel experiences and travel information in an interactive manner (Leung et al., 2013). As a result, social media is influencing the decision-making process of consumers when booking a hotel (Hudson and Thal, 2013; Varkaris and Neuhofer, 2017). However, the importance of social media has not only opened new opportunities for brand-customer interactions but has also brought new challenges for management (Jakic et al., 2017). Over the past decades, social media platforms have complemented and even replaced traditional tourism information sources such as travel magazines, books, and newspapers (Chung and Koo, 2015).

While brands are used to communicate with consumers in a non-interactive and one-way manner through traditional marketing communication channels (e.g. television, radio and printed media; Hennig-Thurau et al., 2010), social media communication resembles a personal and interactive conversation. In contrast to traditional brand-customer interactions, brands are increasingly using an informal style in their social media communication (Beukeboom et al., 2015; Gretry et al., 2017), including the use of graphical icons that express emotions, known as emotional icons, emojis, or emoticons. These icons represent depictions of mimic expressions and have extended the punctuation system to express emotions or mood of the sender (Albert, 2015; Huang et al., 2008). Despite the important role of brandcustomer interactions in social media, little research has explicitly addressed brands' language use and their potential contribution to building brandcustomer relationships (Jakic et al., 2017).

Barcelos et al. (2018) show that the tone of voice used by firms influences behavioral intention on social media, and that such an influence is mediated by the hedonic value of the consumer's experience with the brand on social media. Their research shows that a more human tone of voice has a higher impact on purchase intention than a corporate tone of voice especially in low-risk decisions. The authors suggest examining the parameters through which communication style on social media influences consumer attitudes and behaviors. For example, a tone of voice may elicit different consumer expectations depending on the brand's positioning. Thus, the role of brand positioning in choosing the appropriate tone of voice when communicating through social media could act as a moderator. Therefore, this study addresses the research question on how the interaction of employing different communication styles (formal vs. informal) and different hotel positioning strategies (utilitarian vs. hedonic) impact consumers' perceptions and booking intentions in the hotel industry. Furthermore, as the implementation of a certain communication style can be an expression of positioning, the perceived fit between these two elements is likely to have an impact on consumers' brand perception. Hence, this study additionally explores whether the fit between communication style and hotel positioning mediates the relationship on brand attitude and booking intention.

\section{Theoretical framework}

The linguistic literature usually categorizes language styles into two, namely informal communication style and formal communication style (Baron, 2003). McArthur (1992) defined an informal communication style as "common, non-official, familiar, casual, and often colloquial, and contrasts in these senses with formal" (p. 516). Gretry et al. (2017) showed that the informal style is perceived as personal, not distant, and friendly in a social media environment. Biber (1986) claims that an informal communication style is associated with spoken language and a formal style with written language. According to Delin (2005), following Fairclough (1994), an informal style involves the use of linguistic features commonly associated with a conversation.

Based on prior research, concrete linguistic features of an informal style in social media settings are identified (Biber, 1986; Delin, 2005; Gretry et al., 2017; Kwon and Sung, 2011; Pearce, 2005) and depicted in Table 1. For example, The Charles Hotel in Cambridge Massachusetts, a four-star hotel, adopts a more informal communication style on their Facebook page by replying to a customer who wrote "love the new rooms" "We do too [customers name]! (ㄱ), (:), (-) Can't wait to show them off on our website!" While the Marriott Hotel uses a more formal communication style when replying to their customers: "Hello [customer name], we would like to share your concerns with the hotel's leadership team. Please send us a private message with your contact information, confirmation number and name on the reservation. Thank you." A formal style is associated with paying attention to strict language rules especially correct grammar and spelling (Gretry et al., 2017).

Some authors have already examined how formal and informal language is associated with social relationships (Fairclough, 1992; Goodman and Graddol, 1996; Halliday and Hasan, 1989; Myers, 1994; Webster and Sundaram, 2009). Pearce (2005) noted that writing has become more informal and closely resembles the informality of colloquial language. 
Table 1. Linguistic features of an informal communication style.

\begin{tabular}{|c|c|c|}
\hline Informal linguistic features & Example & References \\
\hline First names & "Hi Alex" & Barcelos et al. (2018); Gretry et al. (2017) \\
\hline $\begin{array}{l}\text { Abbreviations and } \\
\text { contractions }\end{array}$ & $\begin{array}{l}\text { “Hi”, “Thanks”, “That's”, } \\
\text { "We're”, “LOL”, “OMG” }\end{array}$ & $\begin{array}{l}\text { Biber (1986); Delin (2005); Gretry et al. (2017); } \\
\text { Kwon and Sung (2011); Pearce (2005) }\end{array}$ \\
\hline Emoticons & (-), $:-()$ & Gretry et al. (2017); Kwon and Sung (2011) \\
\hline Capitalization & FOLLOW US, WOW & Kwon and Sung (2011) \\
\hline Repeated punctuation & “!!!”, “...","!” & $\begin{array}{l}\text { Delin (2005); Gretry et al. (2017); } \\
\text { Kwon and Sung (2011) }\end{array}$ \\
\hline Informal vocabulary & "Great", “Awesome" & Biber (1986); Delin (2005); Gretry et al. (2017) \\
\hline Sound mimicking & $\begin{array}{l}\text { “Ahhhhhh”, “Ooopsy”, } \\
\text { "Awww”, “Soooo”" }\end{array}$ & Kwon and Sung (2011) \\
\hline Lexical bundles & $\begin{array}{l}\text { "That's what we like to hear", } \\
\text { "That's awesome" }\end{array}$ & Pearce (2005) \\
\hline Pro-verbs (verb omission) & $\begin{array}{l}\text { "There are no hotels in" vs. } \\
\text { "No hotels in" }\end{array}$ & Biber (1986) \\
\hline Common verbs & $\begin{array}{l}\text { "Waiting for you" vs. } \\
\text { "Looking forward to } \\
\text { hosting you" }\end{array}$ & Pearce (2005) \\
\hline $\begin{array}{l}\text { Personal pronoun } \\
\text { first- and second- } \\
\text { person pronouns }\end{array}$ & "You", "we", "us" & Biber (1986); Pearce (2005) \\
\hline $\begin{array}{l}\text { Informal address } \\
\text { (e.g. Dutch, French, } \\
\text { German language) }\end{array}$ & “jij, je”, "tu, toi”, "du, dir“ & Besch (1998) \\
\hline
\end{tabular}

Delin (2005) investigated the way in which social relationships between brands and potential customers generally are constructed through language. An informal style can be used strategically to convey perceptions of a close relationship with consumers and to reduce social distance (Sundar and Cao, 2020). Additionally, Goodman and Graddol (1996) described how the informalization and the 'conversationalization' of language are used to create an impression of social closeness. The presence of conversational and informal features results in the brand being perceived as a more personally positioned brand (Delin, 2005). Steinmann et al. (2015) show that in contrast to a non-personalized communication style, addressing members of an online brand community with personalized messages increases the consumer's identity with the brand, which should also have a positive impact on consumers' attitude toward the brand.

The results of the studies previously described have two implications. First, brands can use communication style to represent personality or human traits for differentiation. Second, brands can build emotional and symbolic links to their target group (Goldsmith and Goldsmith, 2012; Panigyrakis et al., 2019). Anthropomorphizing brands as a part of a brand's marketing communication strategy can reinforce a long-term business success (Aggarwal and McGill, 2007; Kim et al., 2020; Sreejesh et al., 2020).
Cho (2006) argued that brands communicate with informal language to imbue the brand with personality (i.e., social and human) traits. Using informal language with nonverbal cues (e.g., abbreviations, emoticons, repeated punctuation, capitalization, sound mimicking) contributes to brand humanization (Kwon and Sung, 2011) and makes the brand feel more real and human (Park and Cameron, 2014). The use of nonverbal cues also helps brands to convey emotions (Kwon and Sung, 2011). Informal language including humanized cues tends to address emotions rather than reason. These cues are just as important to the customer experience as functional cues (Berry et al., 2002).

Although brands are increasingly using an informal style when communicating through social media (Beukeboom et al., 2015; Gretry et al., 2017), there is no consistent evidence that using an informal style is the optimal way to communicate with all consumers for all brands. Literature shows that different aspects of informal communication were investigated so far with varying results. While Cruz et al. (2017) show that the inclusion of second person pronouns (e.g., "you") as an informal cue in online brand messaging enhances consumer involvement and brand attitude, Labrecque et al.'s (2020) findings reinforce the context of pronoun choices. Effects of linguistic choices vary across brand type and offerings (goods vs. services). Colliander and Marder (2018) investigate 
another aspect of informal communication. They show that using pictures with a snapshot aesthetic results in higher levels of brand attitude on social media than using formal pictures with a traditional studio aesthetic.

Furthermore, smiling emojis in digital customer service messages elicit positive affect in consumers and enhance the strength of marketing relationships (Casado-Molina et al., 2019; Smith and Rose, 2020). Li et al.'s (2019) research shows that customers perceive service employees who use emoticons as higher in warmth but lower in competence. This concludes with the finding that brands using a taskoriented, thus formal, communication style are characterized as more reliable and credible (Choi et al., 2019; van Dolen et al., 2007). While cognitive evaluations of the brand seem to be more positively influenced by a formal communication style, affective evaluations are more positive when using an informal communication style. While most studies in this field of research look at emotional or cognitive outcomes the question remains how behavioral outcomes are affected.

Whereas Barcelos et al. (2018) show that the use of an informal communication style leads to higher purchase intention, Gretry et al. (2017) found that an informal communication style only improves brand perception for consumers who are familiar with the brand. A formal style of communication is more appropriate for unfamiliar brands. These findings already indicate that communication style needs to be considered in its context. Therefore, a discussion of the moderating effect of positioning is crucial.

Positioning is typically regarded as a distinct brand strategy, which determines important brand characteristics (Delin, 2005). Brands use visual and textual features to implement their positioning perceptibly on the internet. The visualization of brand positioning is displayed through various design elements such as brand logo, corporate design measures (i.e., colors, shapes), or images. The positioning can also increasingly be found in textual elements such as communication style (Delin, 2005). Casado-Molina et al. (2019) emphasize that emojis are not a mere occasional means within a message but rather a differentiating tool for brand positioning.

In Batra and Ahtola's (1991) attempt to measure multiple dimensions of brand perceptions, they found that consumers have two basic reasons for purchasing brands. On the one hand, there is an affective and hedonic gratification, and, on the other hand, an instrumental and utilitarian reason. Their studies reported that consumers' brand perceptions have at least two distinct components, namely the hedonic and the utilitarian. Voss et al. (2003) adopted this two-dimensional conceptualization of brand positioning and developed two distinct measurement scales. The hedonic dimension results from sensations and creates commitment and emotions (Voss et al., 2003). Hedonic and symbolic components create fun and pleasure and lead to fantasies, emotions, and feelings (Holbrook and Hirschman, 1982). According to Voss et al. (2003), the utilitarian dimension is derived from functional needs satisfied by the product. Additionally, Strahilevitz and Myers (1998) stated that the utilitarian attributes are more rational, instrumental, goal oriented, and perform a functional or practical task.

Das et al. (2019) showed that the presence of an emoji only increases positive outcomes when they are shown in advertisements for hedonic instead of utilitarian products. Delin (2005) linguistically examined two different brands, HSBC and Orange, and found a correlation between low-frequency vocabulary items and collocations and brand associations. Davis et al. (2019) show that for less hedonic brands, tweets perceived as easy to read tend to result in greater engagement, and for more hedonic brands, tweets perceived as difficult to read tend to result in greater engagement. As the appropriateness of the communication style influences brand perception and brand value (Gretry et al., 2017), brand communication should reflect the brand's positioning. As the use of a communication style can be an expression of the brand's position, the interaction between brand positioning and social media communication style is likely to have an impact on consumers' brand perception. Based on these assumptions, the perceived fit between the positioning of a hotel and its communication style might represent a non-negligible factor. Informal linguistic features (Berry et al., 2002) and hedonic attributes (Batra and Ahtola, 1991) tend to address emotions. Hence, the combination of an informal (vs. formal) communication style and a hedonic (vs. utilitarian) hotel positioning generates associations with emotion. Thus, it is assumed that the use of an informal (vs. formal) style fits better for hedonic brands. As the utilitarian brand positioning conveys rationality (Batra and Ahtola, 1991), it is assumed that the use of a formal (vs. informal) style has a higher perceived fit for utilitarian brands.

H1a. The adoption of an informal (vs. formal) communication style on social media results in a higher perception of fit for hedonically positioned hotels.

H1b. The adoption of a formal (vs. informal) communication style on social media results in a higher perception of fit for utilitarian positioned hotels. 
Consumers' attitude towards a brand develops from their examination of the brand, the brand's marketing communication, and the discovery of the brand's functional and symbolic attributes through experience with that brand's products or services (Keller, 1993). In addition, the perceived fit of the communication style and the brand's positioning influences brand perception (Gretry et al., 2017).

Chang et al. (2019) found that when the language of the narrative person (first person vs. third person) matches brand image (warmth vs. competence) more user likes are generated. As brand attitude forms the basis for consumer behavior (Keller, 1993), it affects consumers' decision to choose one brand instead of another (Laroche et al., 1996; Solomon, 2014; Spears and Singh, 2004). Behavioral intentions are personal action tendencies (Ostrom, 1969) that refer to a brand and can be defined as a conscious plan to try to approach a brand (Spears and Singh, 2004).

H2. Perceived fit mediates the effects of the interaction between communication style and positioning on

(a) brand attitude and (b) booking intention.

H3. Brand attitude mediates the effects between perceived fit and booking intention.

\section{Methodology}

\section{Design}

We conducted an experiment using a $2 \times 2$ betweensubjects full-factorial design (see Table 2 ). The experimental manipulations involved two communication styles (informal vs. formal) and two hotel positionings (hedonic vs. utilitarian). As we wanted participants to be unfamiliar or to have no prior experience with a specific hotel brand to control for memory effects or prior information about a brand, a fictitious brand was used. Respondents were randomly assigned to one of the four experimental conditions.

First, we created two fictitious Facebook posts from two hotels that differ according to their brand positioning. To manipulate brand positioning (whether it is hedonic or utilitarian), participants received a hotel description with a corresponding picture of the hotel. The hotel with a hedonic positioning was described as a modern spa and sport hotel brand for adventure holidays, whereas the hotel with a utilitarian positioning was described as a functional and efficient hotel designed especially for business trips (for the actual stimulus material in German contact the authors).

Second, to manipulate communication style (formal vs. informal), participants received excerpts of fictitious social media conversations between the hotel brand and customers. To conceptualize and adapt the language styles, the linguistic features presented in Table 1 were used. As these features are directly derived from comparable literature (Biber, 1986; Delin, 2005; Gretry et al., 2017; Kwon and Sung, 2011; Pearce, 2005), a comparison of the findings is feasible.

A factorial design has important benefits. First, it has great flexibility for exploring the "treatment variations" positioning and communication style in this study. Second, factorial designs are efficient. Instead of conducting a series of independent studies these studies can effectively be combined into one. Finally, factorial designs are the only effective way to examine interaction effects ( for more information on experimental designs see Field, 2018; Montgomery, 2013; Oehlert, 2000). Especially, as the interaction effect of hotel positioning and communication style is the major focus of this research, a factorial design is the design of choice.

\section{Sample}

Data were collected through an online survey using the snowball sampling approach. The questionnaire was primarily shared within social media platforms to ensure that research participants are sufficiently experienced with the context of social media communication. Students were asked to further share the link to the online survey on their social media accounts to reach a lager sample that is active on social media platforms. Although snowball sampling leads to a convenience sample not representative of the general population, it allows to reach a target group of social media users closely resembling the target group of companies engaging in social media marketing.

Table 2. Factorial design.

\begin{tabular}{llll}
\hline & & Communication style & \\
\cline { 2 - 3 } & & Formal & Informal \\
\hline Positioning & Hedonic & Group 1: Hedonic \& formal & Group 2: Hedonic \& informal \\
& Utilitarian & Group 3: Utilitarian \& formal & Group 4: Utilitarian \& informal \\
\hline
\end{tabular}


Table 3. Results of the analyses of covariance.

\begin{tabular}{|c|c|c|c|c|c|c|}
\hline & \multicolumn{3}{|c|}{ MANCOVA results } & \multicolumn{3}{|c|}{ ANCOVA results } \\
\hline & Wilks & Df & F-Value & $\begin{array}{l}\text { Perceived fit } \\
\text { F-Value }\end{array}$ & $\begin{array}{l}\text { Brand attitude } \\
\text { F-Value }\end{array}$ & $\begin{array}{l}\text { Booking Intention } \\
\text { F-Value }\end{array}$ \\
\hline \multicolumn{7}{|l|}{ Independent variable } \\
\hline Communication style (CS) & .94 & $3 ; 328$ & $6.58^{* * *}$ & $16.29^{* * *}$ & $13.19 * * *$ & 1.11 \\
\hline Positioning (P) & .92 & $3 ; 328$ & $9.74^{* * *}$ & 1.39 & $6.65^{* *}$ & $28.84^{* * *}$ \\
\hline $\mathrm{CS} \times \mathrm{P}$ & .81 & $3 ; 328$ & $25.78^{* * *}$ & $68.52^{* * *}$ & $6.49 *$ & 0.12 \\
\hline \multicolumn{7}{|l|}{ Covariances } \\
\hline Involvement & .95 & $3 ; 328$ & $6.31 * * *$ & $7.97^{* *}$ & $8.09 * *$ & $15.67^{* * *}$ \\
\hline Social media knowledge & .94 & $3 ; 328$ & $6.50^{* * *}$ & 1.28 & $15.40 * * *$ & $12.77^{* * *}$ \\
\hline Mean square explained & & & & 13.90 & 7.91 & 11.83 \\
\hline Mean square residual & & & & 1.68 & .91 & 1.96 \\
\hline
\end{tabular}

${ }^{*} p<0.05 ;{ }^{* *} p<0.01 ;{ }^{* * *} p<0.001$.

Three hundred thirty-six participants took part in the experiment and finished it completely. The participants consisted of 62 per cent females and 38 per cent males, while the mean age of the participants was pegged at 30.7 years. Sixty-two per cent of the participants were students, 34 per cent employed individuals. Participants were randomly assigned to one of the four scenarios. Fisher's exact test for cross tables was used to analyze whether respondents were successfully randomized according to their demographic characteristics. The results confirmed that randomization was successful. The influence of demographic variables (gender, age, and education) on mediators and dependent variables were tested. No significant results were found. Thus, the authors excluded these variables from the final analysis.

\section{Measures}

The participants first answered the control questions. After reading the brand description and conversation, participants were asked to respond to items measuring the manipulation check and dependent variables. Items were measured on a seven-point Likert scale or a semantic differential scale and were derived from previously validated scales. Online Appendix A contains the complete list of the items, reliability factor loadings, Cronbach's alpha for each scale, and the source adopted for each construct. Seven-point Likert items have been shown to be more accurate, easier to use, and a better reflection of a respondent's true evaluation and especially agreeable with highly educated respondents (Nunnally, 1978). The dependent variable 'perceived fit' of the brand communication style and the brand's positioning were measured with five items. 'Brand attitude' was assessed using a seven-item scale, while four items were used to measure 'booking intention'.

As a manipulation check, participants rated the hotel's utilitarian and hedonic positioning with six items each. Participants rated the informality of the communication style using four items. A pretest confirmed that the independent variables were correctly and successfully manipulated. T-tests were conducted to assess the manipulations in the main study. As intended, participants in the informal condition $(\mathrm{M}=5.06 ; \mathrm{SD}=.78)$ rated the communication style significantly more informal than those in the formal condition $(\mathrm{M}=2.62 ; \mathrm{SD}=.95 ; \mathrm{t}=25.07, \mathrm{p}<.001)$. Additionally, participants in the hedonic condition $(\mathrm{M}=5.97 ; \mathrm{SD}=.93)$ perceived the brand significantly more hedonic than participants in the utilitarian condition $(\mathrm{M}=3.52 ; \mathrm{SD}=1.17 ; \mathrm{t}=21.13, \mathrm{p}<.001)$. Furthermore, participants in the utilitarian condition $(\mathrm{M}=5.95 ; \mathrm{SD}=.78)$ perceived the utilitarian brand significantly more utilitarian than those in the hedonic condition $(\mathrm{M}=4.17 ; \mathrm{SD}=1.12 ; \mathrm{t}=16.79, \mathrm{p}<.001)$. As control variables, we measured product involvement using a five-item scale and social media knowledge with two self-developed items. All scales were reliable with Cronbach's alpha values higher than 0.7 (Nunnally, 1978).

We calculated the Kaiser-Meyer-Olkin (KMO) as well as Bartlett's Test of Sphericity to measure sampling adequacy (Hutcheson and Sofroniou, 1999). The KMO is $.909(>0.5)$ and Bartlett's Test of Sphericity is significant at $<0.001$. Therefore, the data are suitable for factor analysis.

\section{Results}

Exploratory factor analysis, confirmatory factor analysis, MANCOVA, and structural equation modelling 
using SPSS AMOS were conducted to test the hypotheses. In the exploratory factor analysis, we also included the manipulation check items and the control variables. The 39 items loaded on the expected eight factors explaining 74 per cent variance in the data. No item loaded lower than 0.4 on the expected factor or had a substantial double loading with another factor (Field, 2018). The single method test of Harman was used to test for common method variance (Harman, 1976). The factor analysis produced neither a single factor nor one general factor that accounted for most of the variance. Each factor accounted for more than the viable cut-off of $5 \%$. Thus, there is no indication that common method variance causes a problem. To assess multicollinearity, we ran a series of regressions models on the various constructs to calculate the variance inflation factor (VIF) (Kleinbaum et al., 1988). The VIF values ranged from 1.12 to 2.33 , which can be considered unproblematic. Literature suggests VIF values of 5 or 10 and above indicate a multicollinearity problem (O'Brien, 2007). Confirmatory factor loading showed no substantial double loadings and all factor loadings are higher than 0.4 (Field, 2018). Convergent validity was examined by calculating the average variance extracted (AVE) and the construct reliability (CR). AVE and CR values are above the recommended values of .50 (Fornell and Larcker, 1981) and .60 (Bagozzi and Yi, 1988), respectively. Additionally, all AVE values are higher than the squared inter-construct correlation (SIC) estimates, thus discriminant validity is established (see online Appendix B).

MANCOVA was conducted to assess the relationship between the independent variables, dependent variables, and the control variables. Homogeneity of variances in the ANOVAs was assessed by Levene's test. All values of significance are higher than .10, thus homogeneity of variance can be assumed.

Subsequently, we ran a multi-group structural equation model to account for latent variables as dependent constructs (Bagozzi, 1977; Bagozzi and Yi, 1989; 2012; Breitsohl, 2019). Measurement invariance was tested using the procedure recommended by Steenkamp and Baumgartner (1998). By placing increasingly restrictive constraints on a multiple-group measurement model, we tested the changes in the model fit for significance. Our model suggests acceptable model fit (see online Appendix C). The $\chi 2$ difference test suggests differences between the models, thus our moderator has an influence on the model. Lastly, we utilized the Preacher et al. (2007) bootstrapping approach to mediation as a test of indirect effects. We tested the mediating effect of perceived fit on brand attitude. The results of our analyses are described below.
Findings of the MANCOVA show that our independent variable (communication style) significantly influences perceived fit and brand attitude, while it has no significant influence on booking intention (see Table 3). The same outcome holds true for the interaction between communication style and positioning. These findings suggest that assessing our hypotheses is justified. The results indicate for communication style a significant main effect on perceived fit and brand attitude. A formal communication style $(M=3.13, S D=1.39)$ leads to significantly lower fit compared to an informal communication style $(\mathrm{M}=3.73 ; \mathrm{SD}=1.49 ; \mathrm{F}=16.29 ; \mathrm{p}<.01)$. Additionally, a formal communication style $(M=2.43$, $\mathrm{SD}=.93$ ) significantly leads to a more favorable brand attitude than an informal communication style $(\mathrm{M}=2.81 ; \mathrm{SD}=1.09 ; \mathrm{F}=13.19 ; \mathrm{p}<.01)$.

Interaction analysis shows that positioning is a moderator (see Figure 1). The interaction effect on perceived fit suggests that a hedonic hotel would benefit from an informal communication style $(M=4.97$, $\mathrm{SD}=.1 .33$ ) compared to a formal communication style $(M=4.34, \mathrm{SD}=1.52)$, while a utilitarian hotel achieves a higher perceived fit by employing a formal communication style $(M=5.37, \quad S D=1.03)$ compared to an informal communication style $(M=3.60, \quad S D=1.33 ; \quad F=68.52 ; p<0.01)$. These findings support hypotheses $\mathrm{H} 1 \mathrm{a}$ and $\mathrm{H} 1 \mathrm{~b}$. For a utilitarian hotel, on the one hand, a formal communication style $(\mathrm{M}=5.57, \mathrm{SD}=.86)$ leads to a more favorable attitude than an informal communication style $(M=4.91, S D=1.14)$. On the other hand, for a hedonic hotel, the communication style seems to be irrelevant (formal: $M=5.56, \quad S D=.97$; informal: $\mathrm{M}=5.48, \mathrm{SD}=.97 ; \mathrm{F}=6.49 ; \mathrm{p}=0.01)$.

The structural equation model confirms our previous findings (see Figure 2). Furthermore, there is a significant effect from perceived fit to brand attitude both for hedonic $(B=.56 ; p<.001)$ as well as utilitarian brands $(\beta=.80 ; p<.001)$. Moreover, while fit has a significant negative effect on booking intention in case of hedonic brands $(B=-.23 ; p=.003)$ but not for utilitarian brands $(B=-.16 ; p=.079)$, brand attitude has a significant positive effect on booking intention for both brand types (hedonic: $\beta=.81 ; p<.001$; utilitarian: $\beta=.80 ; \mathrm{p}<.001)$.

To test for the strength of our mediation effects, we utilized the Preacher et al. (2007) bootstrapping approach as a test of indirect effects. The results show that perceived fit $(b=.43, \mathrm{BCa}$ CI $[.37 ; .50])$ partially mediates the effect of communication style as well as its interaction with brand positioning on brand attitude. The direct effect of communication style $(b=.19, p<.01)$ and the interaction effect 


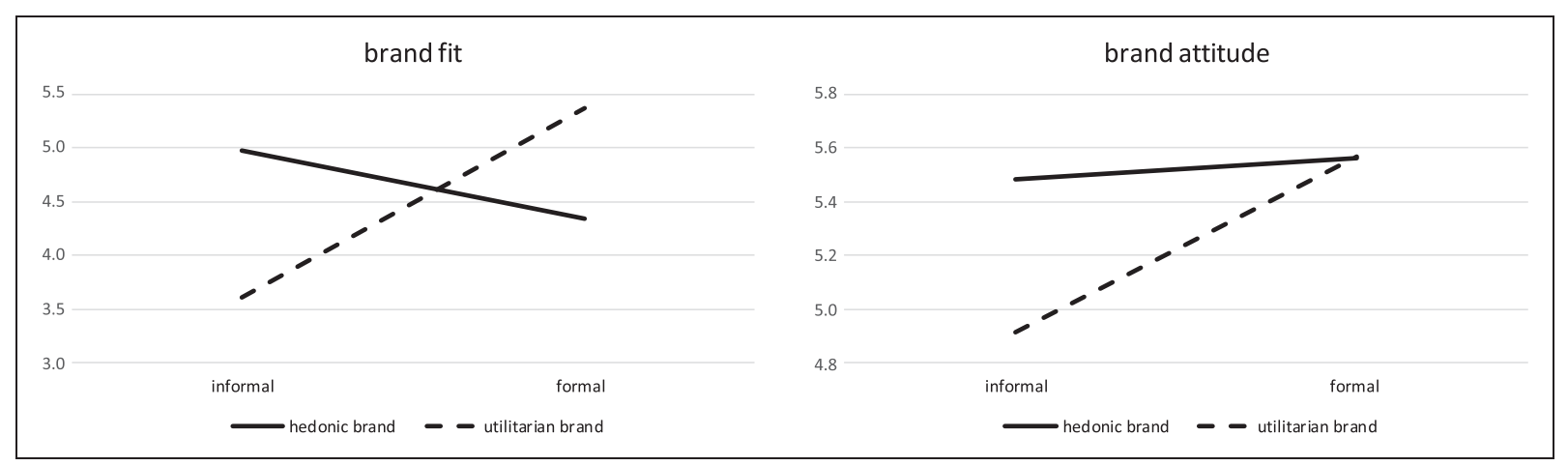

Figure 1. Interaction effects of communications style and positioning on brand attitude and perceived fit.

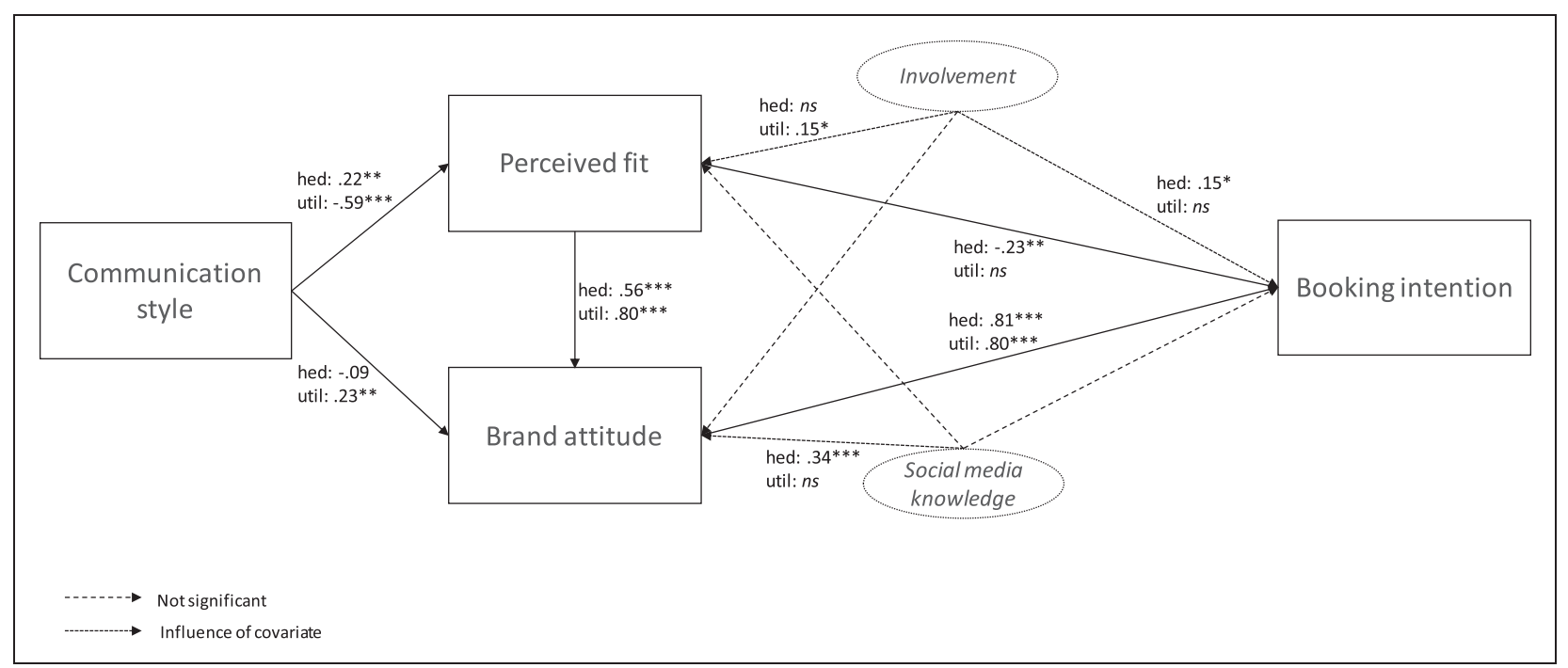

Figure 2. Results of the test of the structural model.

$(\mathrm{b}=-.18, \mathrm{p}<.01)$ on brand attitude are still significant. Additionally, brand attitude partially mediates the relationship between perceived fit and booking intention $(b=1.05$, BCa CI $[.91 ; 1.22])$. The direct effect of perceived fit $(b=-.14, p=.011)$ on booking intention is still significant. Thus, our hypotheses $\mathrm{H} 2$ and $\mathrm{H} 3$ are partially confirmed.

\section{Discussion}

The use of social media, as described in the introduction of this article, has become increasingly important for hotel brands, and offers indispensable platforms for marketing communication in the hospitality industry. The multitude of daily interactions between brands and consumers on these platforms suggests that guidelines are needed on how hotels should communicate with consumers. These guidelines can help managers to develop an appropriate communication style, evoke a better consumer attitude towards their brand, and increase consumers' behavioral intention.

Despite the tendency for brands to increasingly use an informal style in their social media communication, our study shows that the use of an informal style of communication can be inappropriate when considering the positioning of the hotel brand. Overall, the adoption of an informal communication style on social media results in a less favorable brand attitude but does not result in a lower booking intention. Although the adoption of an informal communication style on social media for brands with hedonic brand positioning yields a higher perceived fit, it does not lead to a more favorable brand attitude. For brands with utilitarian positioning, the adoption of a formal communication style on social media results in an even higher perceived fit and a more favorable brand attitude. 
From a theoretical perspective, the results of this study add to the emerging literature on social media communication (e.g., Labrecque et al., 2020; Panigyrakis et al., 2019), by exploring the relationship between formal and informal communication styles and perceived fit with the hotel positioning strategy which was not previously empirically examined. Our study also endeavors to uncover the route through which the perceived fit between communication style and brand positioning influences purchase intentions, by exploring their effect on brand attitude. These findings add novel insights to the communication style literature by showing that communication style - if used in line with brand positioning - can effectively be employed to enhance brand attitude. Second, we add new insights by exploring a behavioral outcome (booking intention) instead of company evaluation (Smith and Rose, 2020). This adds to scarce literature of communication styles on behavioral responses. Previous literature in this field show inconsistent results (Barcelos et al., 2018; Gretry et al., 2017).

Our research underlines that context is very important for the investigation of communication styles which concludes to our third contribution: hotel positioning moderates the effect of communication style on consumer evaluations. Posts using an informal communication style only lead to higher positive evaluations when the hotel positioning is hedonic, not when it is utilitarian. This research finding casts doubts on what has been suggested in previous research that aspects of informal communication style influence brand attitude in a positive way (Barcelos et al., 2018). Especially, for hotels with a utilitarian positioning the fit of its communication style strongly influences brand attitude and, therefore, purchase intention. Thus, fit between communication style and hotel positioning is crucial and an informal communication style is only appropriate for hedonic positioning strategies. Finally, our study extends the literature on fit leading to positive consumer behavior (e.g., Bridges et al., 2000). Looking at the effect of the fit between communication style and the hotel positioning is new and emphasizes the importance of fit across a variety of consumer contexts (Das et al., 2019).

\section{Industry implications}

The results of this study have relevant implications for social media managers. What becomes apparent from our research is the need for companies to seriously consider the importance of a message style beyond its content. This research also shows that the success of a brand does not only depend on what is said but also on how it is said. Communicating and, thereby, maintaining brand positioning is essential to long-term success (Bhat and Reddy, 1998). As this study also shows, people react differently to the same brand communication depending on the brand's positioning. General guidelines for the choice of the style of hotel brand communication can be derived. Based on the findings of the empirical study, the efficiency of social media communication is increased when the following instructions are implemented.

For a hedonic brand, adopting an informal communication style on social media is not harmful because it results in a higher fit. Nevertheless, the adoption of an informal communication style of a hedonic brand does not lead to a more favorable attitude. Thus, the benefits of using an informal communication style are limited. For hotel brands with utilitarian brand positioning, on the contrary, it is not advisable to adopt an informal communication style as it results in lower fit and a less favorable brand attitude. Therefore, brands with utilitarian positioning are strongly advised to communicate in a more formal way. Accordingly, managers should be fully aware of their brand's positioning before adapting an informal style used by the majority (Beukeboom et al., 2015). Even though it is common to communicate informally on social media, our results suggest that it is rarely preferred by consumers.

Overall, a higher perception of fit leads to a more favorable brand attitude and higher booking intention. Nevertheless, our results suggest a partial mediation, leading to the conclusion that there are other factors, aside from fit, that can influence the perception of a brand on social media.

\section{Limitations \& future research}

This article has certain limitations that directly lead to opportunities for future research. In the study, two brands with the same product are used to simulate different positioning. Thus, distortion effects or different levels of involvement were minimized. Future research should investigate additional brand pairs in order to show and replicate this effect for other product categories.

This article focused only on one social medium Facebook - as it is currently the most used social media platform by consumers and the most relevant for marketing (Hutchinson, 2018). It is assumed that the results can also be applied to other social media platforms and other two-way communication contexts where interactions between consumers and brands take place. Future studies could extend the present findings by testing the effects of communication style on different social media (e.g., Instagram) or in direct 
communication (e.g., e-mail) to prove that the findings are not a Facebook-specific phenomenon.

To generalize the distinction between informal and formal styles of communication, additional communication elements could be included in a future study. Going beyond text, visual, and audible cues can be integrated in a more complex research setting to create a more impactful simulation of an informal communication style. Furthermore, real conversations from social networks could be examined to see how certain language styles affect the reaction of users or commitment in the form of comments and likes.

Depending on the brand positioning, this article determines the best communication strategies that could be used when interacting with consumers. This assumption differentiates brands into only two groups (hedonic vs. utilitarian). Moreover, brands can be classified in various ways. While Gretry et al. (2017) distinguished between familiar and unfamiliar brands; the perceived brand perception may also differ depending on the five dimensions of the brand personality (Aaker, 1997) or the age of the brand (young vs. old brands). For example, young brands may be associated with an informal communication style and old brands with a formal communication style. Consumers might expect brands with a competent personality to use a more formal communication style, whereas brands with a rugged personality might be expected to employ a more informal communication style.

Another research direction could concentrate on the role of consumer motivation. In our study, participants were instructed to read a Facebook conversation excerpt to create a perception of the fictitious and new brand. This could be goal-directed behavior, as it is extrinsically and instrumentally motivated. However, consumers have different intentions or motives for using social media brand pages. Some consumers use social media sites to inform themselves, others to interact and create content (Cheung et al., 2011). Depending on the motivation for usage, different communication styles can be suitable. In further research, participants could be given the opportunity to interact with brands instead of passively reading the interactions between consumers and brands. Thus, the goals and intentions of consumers interacting with brands on the social media site can be explored.

\section{Declaration of Conflicting Interests}

The author(s) declared no potential conflicts of interest with respect to the research, authorship, and/or publication of this article.

\section{Funding}

The author(s) received no financial support for the research, authorship, and/or publication of this article.

\section{ORCID iD}

Sabrina M Hegner (D) https://orcid.org/0000-0003-49013657

\section{Supplemental Material}

Supplementary material for this article is available online.

\section{References}

Aaker JL (1997) Dimensions of brand personality. Fournal of Marketing Research 34(3): 347-356.

Aggarwal P and McGill AL (2007) Is that car smiling at me? Schema congruity as a basis for evaluating anthropomorphized products. Fournal of Consumer Research 34(4): $468-479$.

Albert G (2015) Semiotik und syntax von emoticons. Zeitschrift Für Angewandte Linguistik 62(1): 3-22.

Bagozzi RP (1977) Structural equation models in experimental research. Fournal of Marketing Research 14(2): 209-226.

Bagozzi RP and Yi Y (1988) On the evaluation of structural equation models. Fournal of the Academy of Marketing Science 16(1): 74-94.

Bagozzi RP and Yi Y (1989) On the use of structural equation models in experimental designs. Fournal of Marketing Research 26(3): 271-284.

Bagozzi RP and Yi Y (2012) Specification, evaluation, and interpretation of structural equation models. Fournal of the Academy of Marketing Science 40(1): 8-34.

Barcelos RH, Dantas DC and Sénécal S (2018) Watch your tone: How a brand's tone of voice on social media influences consumer responses. Fournal of Interactive Marketing 41: 60-80.

Baron NS (2003) Language of the internet. Available at: http://nl.ijs.si/janes/wp-content/uploads/2014/09/ baron2003.pdf/ (accessed 18 February 2020).

Batra R and Ahtola OT (1991) Measuring the hedonic and utilitarian sources of consumer attitudes. Marketing Letters 2(2): 159-170.

Benevolo C and Spinelli R (2016) Evaluating the quality of web communication in nautical tourism: A suggested approach. Tourism and Hospitality Research 18(2): 229-241.

Berry L, Carbone L and Haeckel S (2002) Managing the total customer experience. MIT Sloan Management Review 43(3): 85-89.

Besch W (1998) Duzen, Siezen, Titulieren: Zur Anrede im Deutschen Heute Und Gestern. 2nd ed. Göttingen: Vandenhoeck and Ruprecht.

Beukeboom CJ, Kerkhof P and de Vries M (2015) Does a virtual like cause actual liking? How following a brand's Facebook updates enhances brand evaluations and purchase intention. Fournal of Interactive Marketing 32: 26-36. 
Bhat S and Reddy SK (1998) Symbolic and functional positioning of brands. Fournal of Consumer Marketing 15(1): 32-43.

Biber D (1986) Spoken and written textual dimensions in English: Resolving the contradictory findings. Language 62(2): 384-414.

Breitsohl H (2019) Beyond ANOVA: An introduction to structural equation models for experimental designs. Organizational Research Methods 22(3): 649-677.

Bridges S, Keller KL and Sood S (2000) Communication strategies for brand extensions: Enhancing perceived fit by establishing explanatory links. Fournal of Advertising 29(4): 1-11.

Casado-Molina AM, Rojas-de Gracia MM, AlarcónUrbistondo P, et al. (2019) Exploring the opportunities of the emojis in brand communication: The case of the beer industry. International fournal of Business Communication. DOI: 10.1177/2329488419832964.

Chang Y, Li Y, Yan J, et al. (2019) Getting more likes: the impact of narrative person and brand image on customer-brand interactions. Fournal of the Academy of Marketing Science 47(6): 1027-1019.

Cheung CM, Chiu PY and Lee MK (2011) Online social networks: Why do students use Facebook? Computers in Human Behavior 27(4): 1337-1343.

Cho S (2006) Interpersonal communication between brands and consumers: A self-presentation study of corporate blogs. New Media Research@ UMN Conference, Minneapolis, MN. Available at: http://citeseerx.ist.psu. edu/viewdoc/download? doi=10.1.1.98.2576\&rep=rep $1 \&$ type $=$ pdf, (accessed 18 February 2020).

Choi S, Liu SQ and Mattila AS (2019) "How may i help you?" says a robot: Examining language styles in the service encounter. International fournal of Hospitality Management 82: 32-38.

Chung N and Koo C (2015) The use of social media in travel information search. Telematics and Informatics 32(2): 215-229.

Cohen H (2018) Fortune 500 social media research: How to make your business succeed. Available at: https:/heidi cohen.com/fortune-500-social-media-research/ (accessed 18 February 2020).

Colliander J and Marder B (2018) Snap happy' brands: Increasing publicity effectiveness through a snapshot aesthetic when marketing a brand on Instagram. Computers in Human Behavior 78: 34-43.

Cruz RE, Leonhardt JM and Pezzuti T (2017) Second person pronouns enhance consumer involvement and brand attitude. Fournal of Interactive Marketing 39: 104-116.

Das G, Wiener HJ and Kareklas I (2019) To emoji or not to emoji? Examining the influence of emoji on consumer reactions to advertising. Fournal of Business Research 96: 147-156.

Davis SW, Horváth C, Gretry A, et al. (2019) Say what? How the interplay of tweet readability and Brand hedonism affects consumer engagement. Fournal of Business Research 100: 150-164.
Delin J (2005) Brand tone of voice: A linguistic analysis of brand positions. Fournal of Applied Linguistics 2(1): 44.

Dodds WB, Monroe KB and Grewal D (1991) Effects of price, brand, and store information on buyers' product evaluations. Fournal of Marketing Research 28(3): 307-319.

Fairclough N (1992) Discourse and Social Change. Cambridge: Polity Press.

Fairclough N (1994) Conversationalization of public discourse and the authority of the consumer. In: Keat R, Whiteley $\mathrm{N}$ and Abercrombie $\mathrm{N}$ (eds) The Authority of the Consumer. London: Routledge, pp.253-268.

Field A (2018) Discovering Statistics Using IBM SPSS Statistics. Thousand Oaks, CA: Sage Publishing.

Fornell C and Larcker D (1981) Evaluating structural equation models with unobservable variables and measurement error. Fournal of Marketing Research 18(1): 39-50.

Goldsmith RE and Goldsmith EB (2012) Brand personality and brand engagement. American fournal of Management 12(1): 11-20.

Goodman S and Graddol D (1996) Redesigning English: New Texts, New Identities. New York: Open University/ Routledge.

Gretry A, Horváth C, Belei N, et al. (2017) Don't pretend to be my friend! When an informal brand communication style backfires on social media. Fournal of Business Research 74: 77-89.

Halliday MAK and Hasan R (1989) Language, Context, and Text: Aspects of Language in a Social-Semiotic Perspective. Oxford: Oxford University Press.

Harman HH (1976) Modern Factor Analysis. 3rd ed. Chicago: The University of Chicago.

Hegner SM and Jevons C (2016) Brand trust: A crossnational validation in Germany, India, and South Africa. Fournal of Product \& Brand Management 25(1): 58-68.

Hennig-Thurau T, Malthouse EC, Friege C, et al. (2010) The impact of new media on customer relationships. Fournal of Service Research 13(3): 311-330.

Holbrook MB and Hirschman EC (1982) The experiential aspects of consumption: Consumer fantasies, feelings, and fun. Fournal of Consumer Research 9(2): 132-140.

Huang AH, Yen DC and Zhang X (2008) Exploring the potential effects of emoticons. Information $\mathcal{E}$ Management 45(7): 466-473.

Hudson S and Thal K (2013) The impact of social media on the consumer decision process: Implications for tourism marketing. Fournal of Travel \& Tourism Marketing 30(1-2): 156-160.

Hutcheson GD and Sofroniou N (1999) The Multivariate Social Scientist: Introductory Statistics Using Generalized Linear Models. London, UK: Sage Publications Ltd.

Hutchinson A (2018) SMT's 2018 social media spending survey - Part 1: Key channels of focus. Available at: www.socialmediatoday.com/news/smts-2018-socialmedia-spending-survey-part-1-key-channels-of focus/ 542521/?fbclid=IwAR3F3cawxtAX3Q5Y-1 m7eCVK- 
pImeSiSbL7eBc4-wm5SiTIs9E6-YhvbCXI (accessed 18 February 2020).

Jahn B and Kunz W (2012) How to transform consumers into fans of your brand. Fournal of Service Management 23(3): 344-361.

Jakic A, Wagner MO and Meyer A (2017) The impact of language style accommodation during social media interactions on brand trust. Fournal of Service Management 28(3): $418-441$.

Keller KL (1993) Conceptualizing, measuring, and managing customer-based brand equity. Fournal of Marketing 57(1): 1-22.

Kim T, Sung Y and Moon JH (2020) Effects of brand anthropomorphism on consumer-brand relationships on social networking site fan page: The mediating role of social presence. Telematics and Informatics 51: 101406.

Kleinbaum D, Kupper L and Muller K (1988) Applied Regression Analysis and Other Multivariable Methods. Boston, MA: PWS-Kent Publishing.

Kwok L, Mao Z and Huang YK (2019) Consumers' electronic word-of-mouth behavioral intentions on Facebook: Does message type have an effect? Tourism and Hospitality Research 19(3): 296-307.

Kwok L and Yu B (2016) Taxonomy of Facebook messages in business-to-consumer communications: What really works? Tourism and Hospitality Research 16(4): 311-328.

Kwon ES and Sung Y (2011) Follow me! Global marketers' twitter use. Fournal of Interactive Advertising 12(1): 4-16.

Labrecque LI, Swani K and Stephen AT (2020) The impact of pronoun choices on consumer engagement actions: Exploring top global brands' social media communications. Psychology \& Marketing 37(6): 796-814.

Laroche M, Kim C and Zhou L (1996) Brand familiarity and confidence as determinants of purchase intention: An empirical test in a multiple Brand context. Fournal of Business Research 37(2): 115-120.

Leung D, Law R, Van Hoof H, et al. (2013) Social media in tourism and hospitality: A literature review. Fournal of Travel E Tourism Marketing 30(1-2): 3-22.

Li X, Chan KW and Kim S (2019) Service with emoticons: How customers interpret employee use of emoticons in online service encounters. Fournal of Consumer Research 45(5): 973-987.

Loo PT (2020) Exploring airline companies' engagement with their passengers through social network: An investigation from their Facebook pages. Tourism Management Perspectives 34: 100657.

McArthur T (1992) The Oxford Companion to the English Language. Oxford, UK: Oxford University Press.

MacKenzie SB and Lutz RJ (1989) An empirical examination of the structural antecedents of attitude toward the ad in an advertising pretesting context. Fournal of Marketing 53(2): 48-65.

Montgomery DC (2013) Design and Analysis of Experiments. 8th ed. Hoboken, NJ: Wiley.
Myers G (1994) Words in Ads. London: E. Arnold.

Nunnally JC (1978) Psychometric Theory. 2nd ed. New York: McGraw-Hill.

O'Brien RM (2007) A caution regarding rules of thumb for variance inflation factors. Quality \& Quantity 41(5): 673-690.

Oehlert G (2000) A First Course in Design and Analysis of Experiments. Revised ed. New York City: W. H. Freeman and Company.

Ostrom TM (1969) The relationship between the affective, behavioral, and cognitive components of attitude. Fournal of Experimental Social Psychology 5(1): 12-30.

Panigyrakis G, Panopoulos A and Koronaki E (2019) All we have is words: Applying rhetoric to examine how social media marketing activities strengthen the connection between the Brand and the self. International fournal of Advertising 39(5): 699-620.

Park H and Cameron GT (2014) Keeping it real. fournalism E Mass Communication Quarterly 91(3): 487-507.

Pearce M (2005) Informalization in UK party election broadcasts 1966-97. Language and Literature: International fournal of Stylistics 14(1): 65-90.

Preacher KJ, Rucker DD and Hayes AF (2007) Addressing moderated mediation hypotheses: Theory, methods, and prescriptions. Multivariate Behavioral Research 42(1): 185-227.

Smith LW and Rose RL (2020) Service with a smiley face: Emojional contagion in digitally mediated relationships. International fournal of Research in Marketing 37(2): 301-319.

Solomon MR (2014) Consumer Behavior: Buying, Having, and Being. 10th ed. New Jersey: Prentice Hall.

Spears N and Singh SN (2004) Measuring attitude toward the brand and purchase intentions. Fournal of Current Issues $\mathcal{E}$ Research in Advertising 26(2): 53-66.

Sreejesh S, Paul J, Strong C, et al. (2020) Consumer response towards social media advertising: Effect of media interactivity, its conditions and the underlying mechanism. International fournal of Information Management 54: 102155.

Steenkamp JBE and Baumgartner H (1998) Assessing measurement invariance in cross-national consumer research. Fournal of Consumer Research 25(1): 78-90.

Steinmann S, Mau G and Schramm-Klein H (2015) Brand communication success in online consumption communities: An experimental analysis of the effects of communication style and brand pictorial representation. Psychology E Marketing 32(3): 356-371.

Strahilevitz M and Myers JG (1998) Donations to charity as purchase incentives: How well they work may depend on what you are trying to sell. Fournal of Consumer Research 24(4): 434-446.

Sundar A and Cao ES (2020) Punishing politeness: The role of language in promoting brand trust. Fournal of Business Ethics 164(1): 39-60. 
Van Dolen WM, Dabholkar PA and De Ruyter K (2007) Satisfaction with online commercial group chat: the influence of perceived technology attributes, chat group characteristics, and advisor communication style. Fournal of Retailing 83(3): 339-358.

Varkaris E and Neuhofer B (2017) The influence of social media on the consumers' hotel decision journey. Fournal of Hospitality and Tourism Technology 8(1): 101-118.

Voss KE, Spangenberg ER and Grohmann B (2003) Measuring the hedonic and utilitarian dimensions of consumer attitude. Fournal of Marketing Research 40(3): 310-320.

Webster C and Sundaram DS (2009) Effect of service provider's communication style on customer satisfaction in professional services setting: The moderating role of criticality and service nature. Fournal of Services Marketing 23(2): 103-113.

Zaichkowsky JL (1985) Measuring the involvement construct. Fournal of Consumer Research 12(3): 341-352.

Zailskaite-Jakste L, Ostreika A, Jakstas A, et al. (2017) Brand communication in social media: the use of image colours in popular posts. In: 40th international convention on information and communication technology, electronics and microelectronics (MIPRO). Available at: https://ieeexplore.ieee.org/ document/7973636 (accessed 18 February 2020).

\section{Author Biographies}

Sabrina M Hegner is a professor of international management at the City University of Applied Science in Bremen, Germany. Her primary research interests include trust creation and maintenance, crisis communication, human-computer interaction, and prosocial behaviours (e.g. charitable giving, ethical consumption).

Carlotta Lotze obtained a Bachelor of Science in Business Psychology at the University of Applied Sciences in Bielefeld, Germany. Her primary research interests include international marketing and organizational as well as consumer psychology, especially consumer-brand relationships.

Ardion Daroca Beldad is an assistant professor of communication science at the University of Twente, the Netherlands. His primary research interests include organizational trust creation and maintenance, determinants and consequences of online trust, information privacy and confidentiality in online and offline contexts, crisis communication, and prosocial behaviours (e.g. charitable giving, ethical consumption). 